\title{
Comparative study of procalcitonin versus c-reactive protein in the diagnosis of sepsis in children below 16 years-a single centre observational study
}

\author{
Simhachalam $\mathbf{M}^{1}$, Vasundhara $A^{2}$, Swetha $L^{3}$, Sudarsini $P^{4}$ \\ ${ }^{1}$ Dr. Simhachalam Malluvalasa, Assistant Professor, ${ }^{2}$ Dr. Vasundhara Arigela, Professor, ${ }^{3}$ Dr. Swetha Lanka, Post Graduate, \\ ${ }^{4}$ Dr. Sudarsini Padala, Professor \& Head of the Department, all authors are affiliated with department of Pediatrics, ASRAM \\ Medical College, Eluru, AP, India.
}

Address for Correspondence: Dr. Simhachalam Malluvalasa, Email: getmsc.doc@gmail.com

\begin{abstract}
Introduction: Given the limitation of non-specific nature of signs, symptoms and physical examination in diagnosing sepsis; especially in young children, a diagnostic marker that will aid in an early diagnosis is needed. Procalcitonin satisfies most of the criteria for smart biomarker of sepsis. The present study is done to compare procalcitonin (PCT) with C-reactive protein (CRP) as a diagnostic marker of sepsis in children. Materials \& Methods: A prospective observational study was done in the Department of Paediatrics, ASRAM Medical College and Hospital, Eluru from July 2015 to June 2016. Children admitted to PICU during the above tenure are included in the study. Specific inclusion and exclusion criteria are formulated with a sample size of 100 . Procalcitonin level is analyzed by enzyme linked immunoluminometric assay using Elecsys Brahms PCT kit.CRP analysis is done using immunoturbidometry which is a quantitative method. Results: Out of 100 children 72 have sepsis. The mean procalcitonin level in children with sepsis is $19.09 \pm 24.53 \mathrm{ng} / \mathrm{ml}$ compared to $0.34 \pm$ $0.49 \mathrm{ng} / \mathrm{ml}$ in children without sepsis. In comparing sepsis with asepsis, PCT (Cutoff value of $0.58 \mathrm{ng} / \mathrm{ml}$ ) have a better sensitivity (90.3\%) and specificity (92.9\%) than CRP (Cut off value of $0.7 \mathrm{mg} / \mathrm{dl}$ ) sensitivity of $87.5 \%$ and specificity of $57.1 \%$. Conclusion: PCT offers better sensitivity and specificity than CRP, to differentiate sepsis from asepsis. In febrile children PCT is a better diagnostic marker of sepsis than CRP.
\end{abstract}

Keywords: Biomarker, C-reactive protein, Procalcitonin, Sepsis.

\section{Introduction}

Fever is the most common reason for visits to paediatrician. Given the limitation of non-specific nature of signs, symptoms and physical examination in diagnosing sepsis; especially in young children, a diagnostic marker that will aid in an early diagnosis is needed. The utility of a biomarker is enhanced if it reflects the severity of infection and progression of the disease as well as the effectiveness of therapy.

Blood culture is the gold standard but requires precious 48 hours and the positivity yield is low. PCT satisfies most of the criteria for smart biomarker of sepsis [1].

Procalcitonin, a polypeptide identical to prohormone of calcitonin is initially described as a potential marker of bacterial disease by Assicot et al[2]. When its elevated levels were reported in patients with bacterial infection, PCT became an important protein in the detection and differential diagnosis of inflammatory states [3].

Manuscript received: $5^{\text {th }}$ January 2017

Reviewed: $14^{\text {th }}$ January 2017

Author Corrected: $20^{\text {th }}$ January 2017

Accepted for Publication: $28^{\text {th }}$ January 2017 


\section{Cut off Values of Procalcitonin}

Plasma PCT has a normal half-life of 25-30 hours and 30-45 hours in patients with severe renal dysfunction. PCT detectable in the plasma during inflammation is not produced by C-cells of the thyroid [3]. The probable sites of PCT production in inflammation are the neuroendocrine cells in the lungs or intestine. The expression of mRNA coding PCT

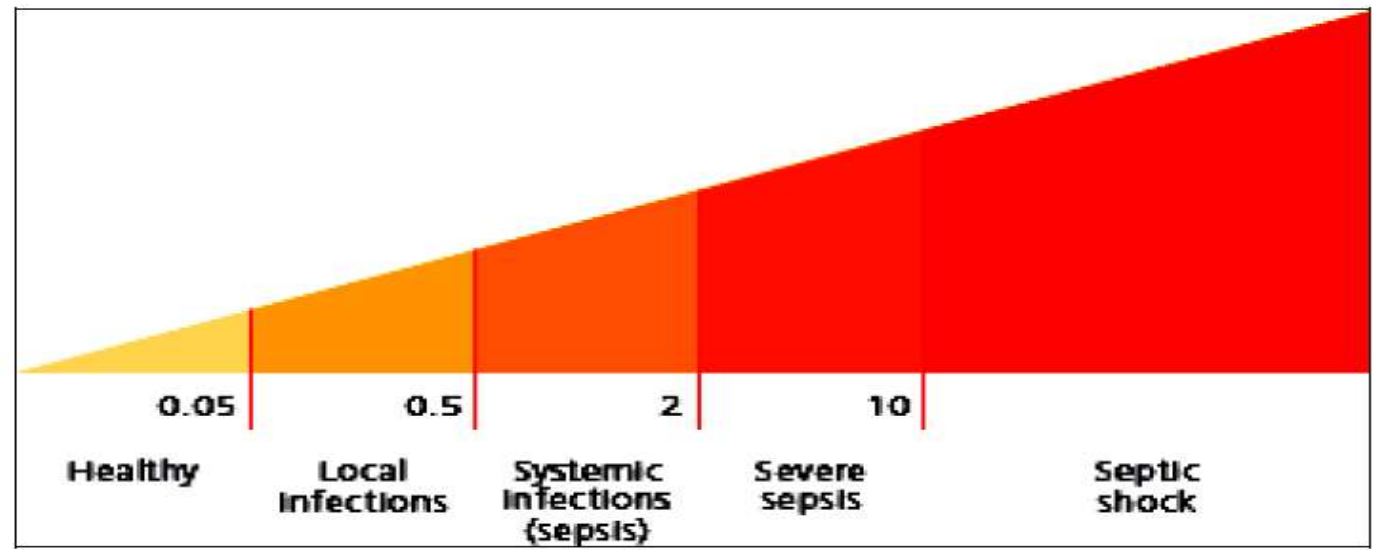

has been demonstrated in vitro in monocytes, stimulated by endotoxin or inflammatory cytokines [4]. PCT is not elevated by viral infections or autoimmune inflammation, or by the presence of neoplasm's [5]. Physiologically PCT can be raised in neonates up to 72 hours. Birth weight and gestation did not significantly affect normal PCT values [6].

Sequential measurements of procalcitonin have shown a rapid fall within 48 hours of antibiotic administration. An immunoluminometric procalcitonin assay is now commercially available (BRAHMS diagnostika) and values can be obtained within two hours of blood sampling.

Volanakis and Kaplan identified the specific ligand for CRP in the pneumococcal C polysaccharide as phosphocholine; part of the techoic acid of pneumococcal cell wall. CRP, an acute phase protein involved in coagulation, acts as opsonin for gram positive bacteria to aid in phagocytosis. CRP is synthesized by the liver in response to and as a part of the inflammatory response. IL-6 is the major stimulus for production of CRP along with IL-1, TNF $\alpha$ [6]. CRP is synthesized within 6-8 hours of exposure to an infective process or tissue damage.

Its half-life is 19 hours and may show a thousand fold rise during an acute phase response. Serial measurements at 24 and 48 hours after the onset of illness considerably improve the sensitivity to $82 \%$ and $84 \%$ respectively [7]. Sequential measurements of CRP levels are helpful in determining the response to anti-microbial therapy and duration of treatment.

Aims and objectives of the study: To compare Procalcitonin (PCT) versus C-reactive protein (CRP) as a diagnostic marker of sepsis in children and to assess the utility of PCT as an early marker in diagnosis of sepsis.

\section{Materials and Methodology}

This is a prospective observational study done in the department of Pediatrics, ASRAM medical college and hospital, a tertiary care centre, Eluru, Andhra Pradesh. The study is conducted from August 2015 to September 2016 over a period of 13 months.

Inclusion criteria: Children less than 16years of age admitted to PICU with rectal temperature of $\geq 38^{\circ} \mathrm{C}$.

Exclusion criteria: Children treated with antibiotics and those who received vaccination in past 48 hrs. Known cases of chronic inflammatory disorder and immunodeficiency are also excluded. 
Sample size calculation: Based on the mean and SD of previous studies [8,9] with an $\alpha$ value of 0.05 and power (1- $\alpha)$ of 0.8 , a sample size of 100 is found to be adequate. Prospective cases were analyzed and data recorded. All children included in the study had fever. Those with symptoms and signs of sepsis are included in sepsis group and rest of the children with no signs and symptoms are included in asepsis group.

Based on International consensus definitions of paediatric sepsis [10,11] children included in the study are divided into two groups - Asepsis and Sepsis. Children satisfying any of the criteria for definite or probable sepsis are included in the sepsis group and the rest are included in asepsis group. After the Institutes ethical committee clearance and informed consent from the guardians, data collected is entered into a structured proforma.

\section{Cohort of Study Identification, Inclusion \& Exclusion}

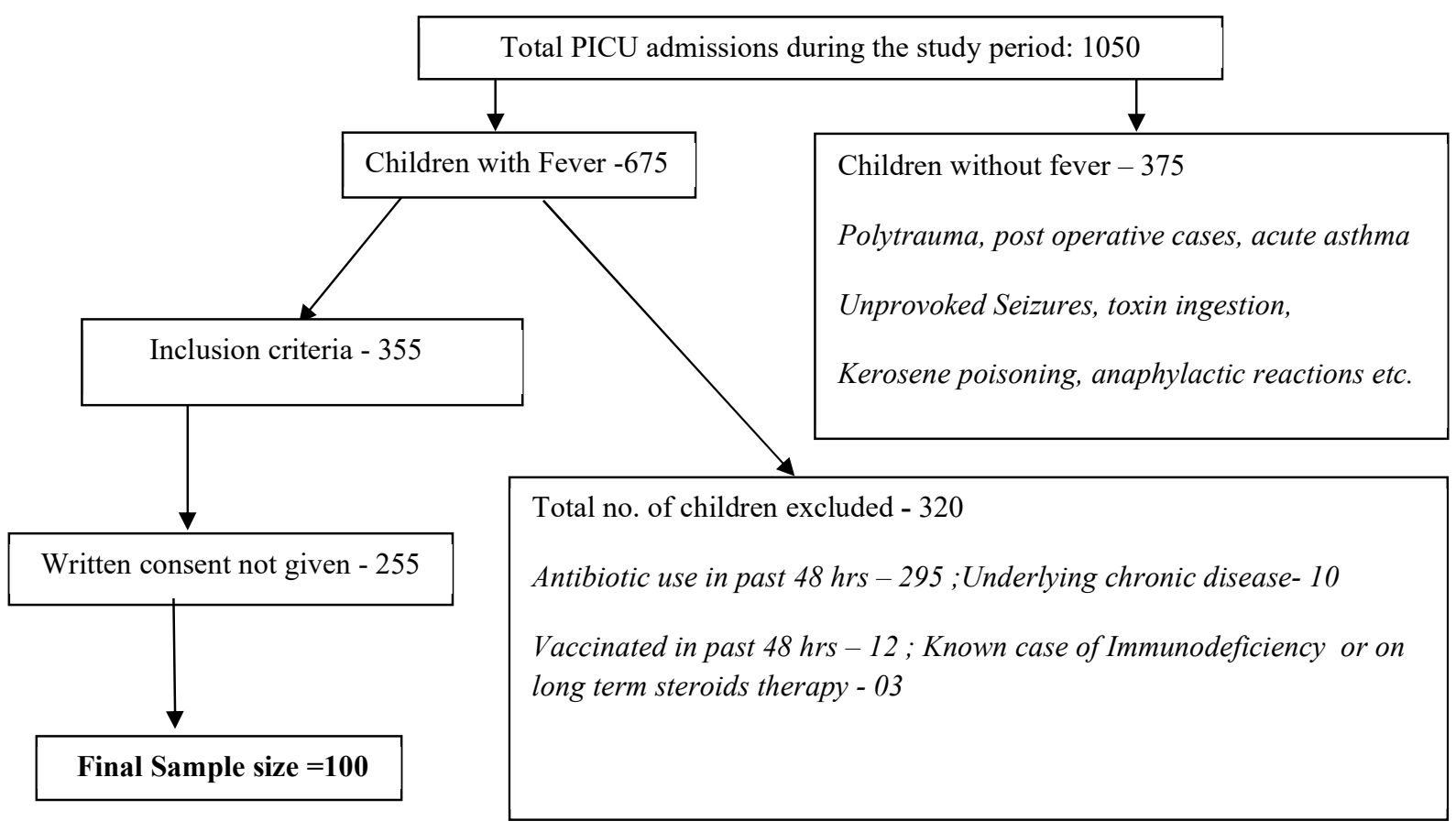

Procalcitonin level analysis is done using enzyme linked immunoluminometric assay by using Elecsys BRAHMS PCT kit.Range:0.02-100 ng/mL. CRP analysis is done using immunoturbidometry, with the minimal detectable concentration being $0.1 \mathrm{mg} / \mathrm{dl}$. Blood culture is done by Bactec-9050/Micro scan system. The data is analyzed using windostat version 8.6 .

\section{Results}

Age distribution: In the present study around half of the study population is between 1-20 months of age and $72 \%$ of the subjects are under 5 years of age indicating that the most common age group with fever requiring PICU admission is $<5$ years.

\begin{tabular}{|l|c|c|c|c|c|}
\hline & \multicolumn{2}{|c|}{ Asepsis } & \multicolumn{2}{c|}{ Sepsis } & P value \\
\hline & Mean & SD & Mean & SD & \\
\hline Age in months & 35.82 & +40.94 & 41.66 & +47.02 & 0.564 \\
\hline
\end{tabular}

Frequency of age distribution among asepsis and sepsis 
Using the student's test for statistics, $95 \%$ confidence limits, it is found that there is no significant difference in the mean age distribution among two groups (sepsis and asepsis). $(\mathrm{p}=0.564)$.

Gender distribution: Of the 100 children included in the study 57 are males and 43 females. The mean age in males is $32.5 \pm 42.5$ months. The mean age in females is $49.9 \pm 47.2$ months. In the present study significant difference does not exist in gender variation among two groups $(p=0.36)$

Procalcitonin: According to our lab reference parameters, PCT $\leq 0.5 \mathrm{ng} / \mathrm{ml}$ is negative and PCT $>0.5 \mathrm{ng} / \mathrm{ml}$ is $\mathrm{positive}$. Among 100 children in the study 33 are PCT negative and 67 are PCT positive. Range: $0.02 \mathrm{ng} / \mathrm{ml}-100 \mathrm{ng} / \mathrm{ml}(\mathrm{mean} 13.8$ $\pm 2.8 \mathrm{ng} / \mathrm{ml})$.

Distribution of PCT among sepsis and asepsis: Number of children with sepsis and asepsis are 72 and 28 respectively. Distribution of PCT among sepsis and asepsis.

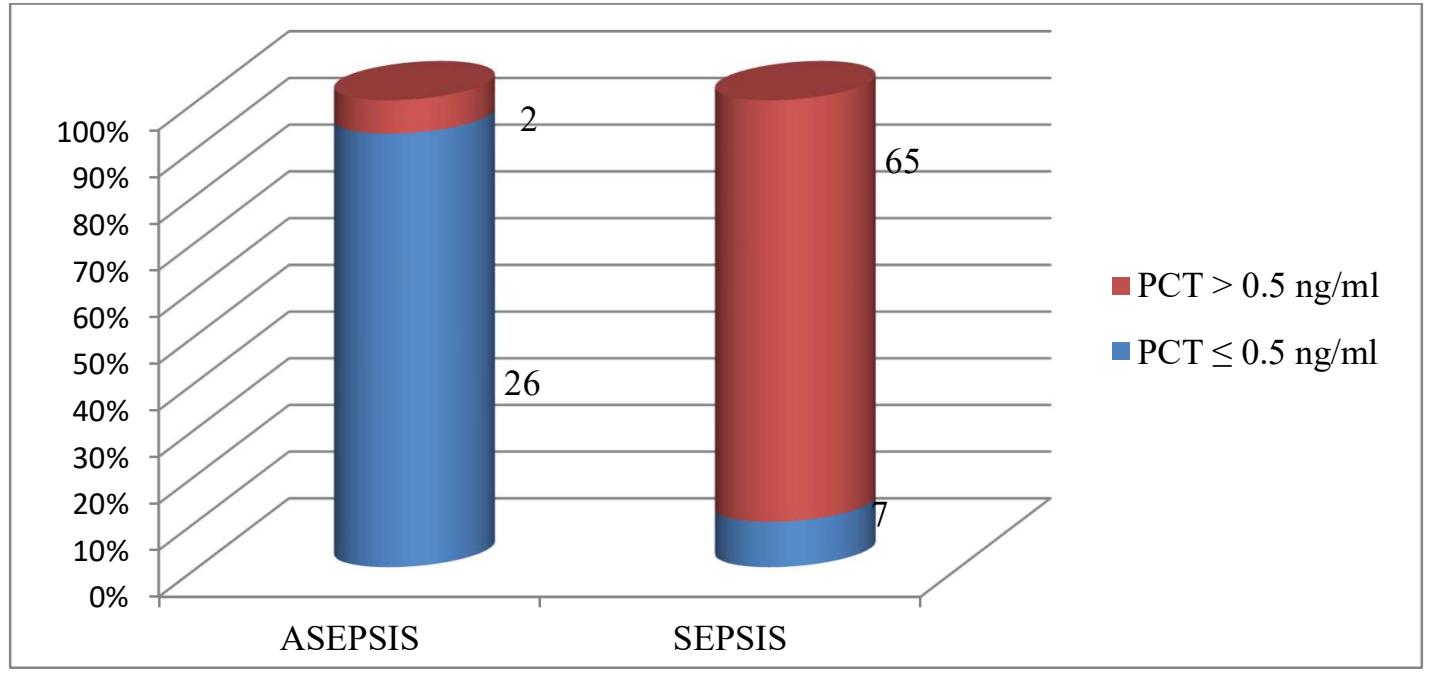

Among 28 patients with asepsis PCT is positive in 2 children (7\%) and negative in 26 children (93\%). Among 72 patients with sepsis PCT is positive in 65 children $(90.3 \%)$ and negative in 7 children $(9.7 \%)$.

\begin{tabular}{|c|c|c|c|c|c|}
\hline & \multicolumn{2}{|c|}{ Asepsis } & \multicolumn{2}{c|}{ Pepsis value } \\
\hline & Mean & SD & Mean & SD & \\
\hline Procalcitonin & 0.34 & 0.49 & $\mathbf{1 9 . 0 9}$ & $\mathbf{2 4 . 5 3}$ & $\mathbf{0 . 0 0 0 1 1}$ \\
\hline
\end{tabular}

The mean of PCT levels among asepsis patients is $0.34 \pm 0.49 \mathrm{ng} / \mathrm{ml}$ and among sepsis patients it is $19.09 \pm 24.53 \mathrm{ng} / \mathrm{ml}$. Using the students test for correlation and $95 \%$ confidence interval, significant statistical difference is noted in levels of PCT measurements among two groups $(\mathrm{p}=0.00011)$.

C- reactive protein: According to our lab reference parameters, $\mathrm{CRP} \leq 0.6 \mathrm{mg} / \mathrm{dl}$-negative and CRP $>0.6 \mathrm{mg} / \mathrm{dl}$-positive. Amongst 100 children 25 are CRP negative and 75 are CRP positive. Range: $0.2 \mathrm{mg} / \mathrm{dl}-21.5 \mathrm{mg} / \mathrm{dl}$ (mean-3.62mg/dl).

Distribution of CRP among sepsis and asepsis: Number of children with asepsis are 28 and sepsis are 72 . Among 28 patients with asepsis CRP is positive in 12 children (42.8\%) and negative in 16 children (57.1\%). Among 72 patients with sepsis CRP is positive in 63 children (87.5\%) and negative in 9 children (12.5\%). 
Distribution of CRP among sepsis and asepsis.

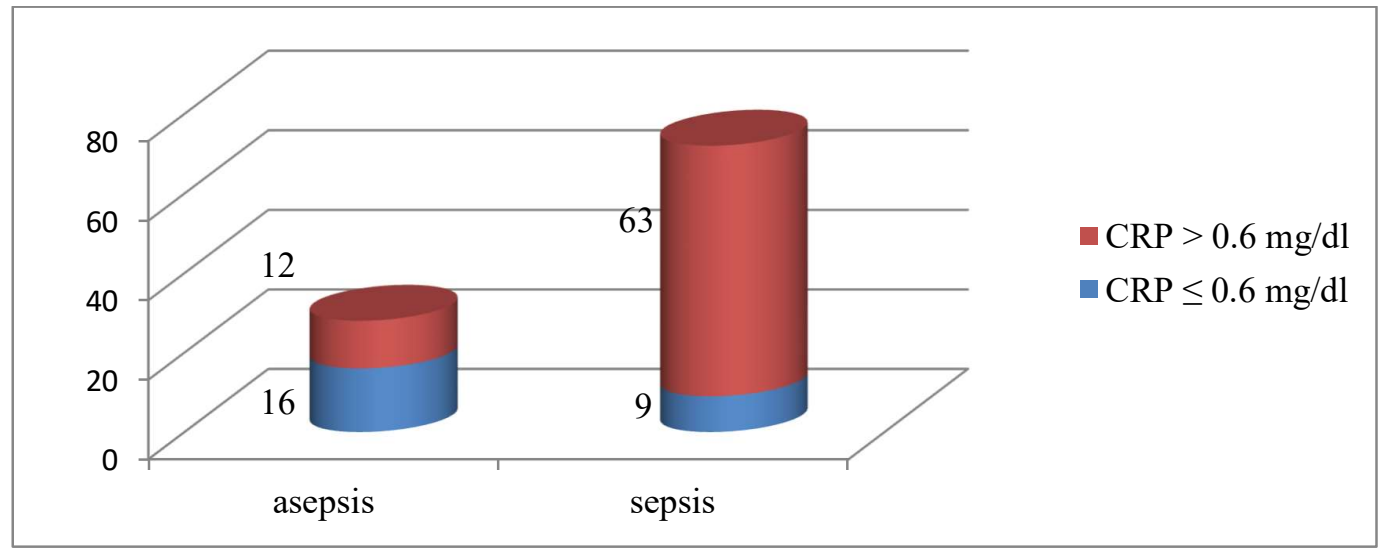

The mean \pm SD CRP levels among asepsis patients are1.38 $\pm 1.71 \mathrm{mg} / \mathrm{dl}$ and among sepsis patients it was $4.49 \pm 4.37$ $\mathrm{mg} / \mathrm{dl}$.

\begin{tabular}{|c|c|c|c|c|c|}
\hline & \multicolumn{2}{|c|}{ Asepsis } & \multicolumn{2}{c|}{ Pepsis value } \\
\hline & Mean & SD & Mean & SD & \\
\hline C-Reactive Protein & 1.38 & 1.71 & $\mathbf{4 . 4 9}$ & $\mathbf{4 . 3 7}$ & $\mathbf{0 . 0 0 0 4 4}$ \\
\hline
\end{tabular}

Using the students' $t$ test for correlation and 95\% confidence interval, significant statistical difference is noted in CRP measurements among two groups.(asepsis and sepsis) $(\mathrm{p}=0.00044)$

Relative sensitivity and specificity at different cut off values of PCT AND CRP:

\begin{tabular}{|c|c|c|c|c|c|}
\hline & $\begin{array}{c}\text { Cut off } \\
\text { value }\end{array}$ & $\begin{array}{c}\text { Sensitivity } \\
(\%)\end{array}$ & $\begin{array}{c}\text { Specificity } \\
(\%)\end{array}$ & $\begin{array}{c}\text { PPV (\%) } \\
\text { Positive predictive } \\
\text { value }\end{array}$ & $\begin{array}{c}\text { NPV (\%) } \\
\text { Negative predictive } \\
\text { value }\end{array}$ \\
\hline \multirow{2}{*}{$\begin{array}{c}\text { PCT } \\
(\mathrm{ng} / \mathrm{ml})\end{array}$} & 0.58 & 90.3 & 92.9 & 97.01 & 78.7 \\
\cline { 2 - 6 } & 1.2 & 75 & 92.9 & 96.4 & 59.09 \\
\hline $\begin{array}{c}\mathrm{CRP} \\
(\mathrm{mg} / \mathrm{dl})\end{array}$ & 0.7 & 87.5 & 57.1 & 84 & 54.8 \\
\cline { 2 - 6 }
\end{tabular}

ROC curve for PCT is constructed comparing children with asepsis and sepsis. These curves are used to identify cut off values and sensitivity and specificity. In comparing asepsis with sepsis the ROC area under the curve (AUC) for PCT is 0.92 , a cut off value of $0.58 \mathrm{ng} / \mathrm{ml}$ yielded.

ROC curve for CRP is constructed comparing children with asepsis and sepsis. These curves are used to identify cut off values and sensitivity and specificity. In comparing asepsis with sepsis the ROC area under the curve (AUC) for CRP is 0.75 , a cut off value of $0.7 \mathrm{mg} / \mathrm{dl}$ yielded.

\begin{tabular}{|l|l|l|l|}
\hline & Culture positive & Culture negative & p value \\
\hline Mean PCT & $22.37 \pm 21.9$ & $27.08 \pm 27.33$ & 0.61 \\
\hline Mean CRP & $5.10 \pm 3.52$ & $5.33 \pm 5.37$ & 0.89 \\
\hline
\end{tabular}

Blood culture and sensitivity: Of 72 patients with sepsis, blood culture is sent in 41 children, of which only 11 (26.8\%) are positive. 
As the blood cultures are sent in children with sepsis, mean values for PCT and CRP are high in both culture positive and culture negative cases. No significant difference in CRP and PCT values, in either culture positive or negative cases.

\section{Discussion}

Interpretation of the literature dealing with Procalcitonin in children is complicated by the diverse age range and nature of the study population and variation in the choice of the cut off value of Procalcitonin.

Age group: Mean age of presentation in our study among asepsis and sepsis is 35.8 and 41.1 months; this age distribution corresponds to other study by Dominique Gendrel et al[12] with 2 subgroups with mean ages of 31.2 and 43.2 months. In a study by Corsino Rey et al [13] mean age was 43.2 months. In a study by Paolo Pecile et al.,[8] mean age was 19 months with $66 \%<1 \mathrm{yr}$.

Gender distribution: In our study 57\% are males and 43\% are females. Study by Corsino Rey et al.,[13] included 59\% males and $41 \%$ females. In the study by Paolo Pecile et al $69 \%$ are females and $31 \%$ are males.

PCT and CRP measurements: In the present study comparing asepsis with sepsis PCT had better sensitivity (90.3 vs. $87.5 \%$ ), specificity (92.9 vs. $57.1 \%)$, PPV (97 vs.84\%), NPV (78.7 vs. $64 \%$ ) than CRP.

\section{Studies in children comparing PCT Versus CRP.}

\begin{tabular}{|c|c|c|c|c|c|c|}
\hline Reference & $\mathbf{N}$ & $\begin{array}{l}\text { Age in } \\
\text { months }\end{array}$ & Test & $\begin{array}{c}\text { Sensitivity } \\
\text { (\%) }\end{array}$ & $\begin{array}{l}\text { Specificity } \\
(\%)\end{array}$ & $\begin{array}{l}\text { AUC(Area under } \\
\text { the curve) }\end{array}$ \\
\hline \multirow{2}{*}{$\begin{array}{l}\text { Fernandez } \\
\text { Lopez[14] }\end{array}$} & 445 & $1-36$ & PCT & 91 & 94 & 0.95 \\
\hline & & & CRP & 78 & 75 & 0.81 \\
\hline \multirow[t]{2}{*}{ Andreola [15] } & 408 & $0-36$ & PCT & 69 & 85 & 0.82 \\
\hline & & & CRP & 84 & 75 & 0.85 \\
\hline \multirow[t]{2}{*}{ Carrol et al[16] } & 108 & $1-192$ & PCT & 94 & 93 & 0.96 \\
\hline & & & CRP & 81 & 89 & 0.90 \\
\hline \multirow{2}{*}{$\begin{array}{c}\text { Vincenzo Maniaci } \\
\text { et al[17] }\end{array}$} & 234 & $0-3$ & PCT & 96.7 & 30.3 & 0.82 \\
\hline & & & WBC & & & 0.66 \\
\hline \multirow[t]{2}{*}{ Paolo Pecile[8] } & 100 & $1-156$ & PCT & 83.3 & 93.6 & \\
\hline & & & CRP & 94.4 & 31.9 & \\
\hline \multirow{2}{*}{$\begin{array}{c}\text { Mark Hatherill } \\
{[18]}\end{array}$} & 175 & $0-193$ & PCT & 100 & 62 & 0.96 \\
\hline & & & CRP & 91 & 62 & 0.83 \\
\hline
\end{tabular}

In a Meta analysis, Liliana Simon et al.,[19] evaluated the accuracy of determination of PCT and CRP levels for the diagnosis of bacterial infection. PCT level was more sensitive (88\% vs. $75 \%$ ) and more specific (81\% vs. $67 \%)$ than CRP level for differentiating bacterial from non-infective causes of inflammation. On the basis of this analysis, the diagnostic accuracy of PCT markers was higher than that of CRP markers among patients hospitalized for suspected bacterial infections. In a study by Fernandez Lopez et al[14] the optimum cut off values suggested for detecting any bacterial infection was $0.53 \mathrm{ng} / \mathrm{ml}$ (sensitivity : 65\% ; specificity: 94\%; PPV : 96\% ;NPV : 59\% ). For detecting invasive bacterial infections was $0.59 \mathrm{ng} / \mathrm{ml}$ (sensitivity: 91.3\%; specificity: $75 \%$; PPV: 69\%; NPV: 81\%).

A study by Mark Hatherill et al., [18]concluded that in critically ill children the admission procalcitonin concentration of $2 \mathrm{ng} / \mathrm{ml}$ or more is a better diagnostic marker of infection than $\mathrm{C}$ reactive protein or leucocyte count. A study by Deis JN et al., [20] compared PCT with interleukin 6 and CRP, and found that IL-6 performed better than PCT which performed better than CRP. 


\section{Conclusion}

In febrile children admitted to paediatric intensive care unit the admission Procalcitonin concentration is a better diagnostic marker of sepsis than $\mathrm{C}$ - reactive protein. A PCT concentration of $0.58 \mathrm{ng} / \mathrm{ml}$ might be useful in differentiating sepsis in infants and children.

Funding: Nil, Conflict of interest: None initiated, Perission from IRB: Yes

\section{Bibliography}

1. YahyaShehabi and Ian Seppelt. Pro/Con debate: Is procalcitonin useful for guiding antibiotic decision making in critically ill patients?Critical Care2008; 12: 211.(doi:10.1186/cc6860) available online athttp:// ccforum. com/content/12/3/211.

2. Assicot M, Gendrel D, Carsin H, Raymond J, Guilbaud J, Bohuon C. High serum procalcitonin concentrations in patients with sepsis and infection. Lancet. 1993 Feb 27; 341 (8844): $515-8$.

3. Russwurm S, Wiederhold M, Oberhoffer M, Stonans I, Zipfel PF, Reinhart K. Molecular aspects and natural source of procalcitonin. Clin Chem Lab Med. 1999 Aug; 37(8):789-97.

4. Oberhoffer M, Stonans I, Russwurm S, Stotane E, Vogelsang H, Junker U, et al: Procalcitonin expression in human peripheral blood mononuclear cells and it's modulation by lipopolysaccharides and sepsis- related cytokines in vitro. J Lab Clin Med. 1999;134: 49-55.

5. Jaresová M, Stríz I, Cermáková J, Lácha J, Sedlácek J, Mudra K, Hána I, Vítko S. Serum procalcitonin concentrations in transplant patients with acute rejection and bacterial infections. Immunol Lett. 1999 Sep 1; 69 (3):355-8

6. Turner D, Hammerman C, Udensky BR, Schlesinger Y, Goai C, Schimmel MS. Procalcitonin in preterm infants during the first few days of life:introducing an age related nomogram. Arch Dis Child Fetal Neonatal 2006; 91: $283-286$.

7. Ng PC, Cheng SH, Chui KM, Fok TF, Wong MY, Wong W, Wong RP, Cheung KL. Diagnosis of late onset neonatal sepsis with cytokines, adhesion molecule, and
C-reactive protein in preterm very low birthweight infants. Arch Dis Child Fetal Neonatal Ed. 1997 Nov;77(3):F221-7.

8. Paolo Pecile, ElisabettaMiorin, Carla Romanello, EdmondoFalleti, Francesca Valent, Francesco Giacomuzzi, and Alfred Tenore,Procalcitonin: A Marker of Severity of Acute Pyelonephritis among Children. Pediatrics 2004; 114: e249 -e254.

9. Chia-Hung Yo, Pei-Shan Hsieh, Si-Huei Lee, JiunnYih Wu, Shy-Shin Chang, Kuang-ChauTasi, et al. Comparison of the Test Characteristics of Procalcitonin to C-Reactive Protein and Leukocytosis for the Detection of Serious bacterial Infections in Children Presenting With Fever Without Source: A Systematic Review and Meta-analysis. Ann Emerg Med. 2012; 60: 591-600.

10. Goldstein B, Giroir B, Randolph A; International Consensus Conference on Pediatric Sepsis. International pediatric sepsis consensus conference: definitions for sepsis and organ dysfunction in pediatrics. Pediatr Crit Care Med. 2005 Jan;6(1):2-8.

11. David A. Turner and Ira M.Cheifetz.Shock. In: Robert M. Kliegman, Bonita F. Stanton, Joseph W. St. Gemelll, Nina F. Schor, Richard E. Behrman, editors. Nelson textbook of paediatrics.Philadelphia,Elsevier; $201620^{\text {th }}$ ed p. 517-522.

12. Dominique Gendrel, Josette Raymond, Marcel Assicot, Florence Moulin, Jean-Luc Iniguez, Pierre Lebon, et al. Measurement of Procalcitonin Levels in Children with Bacterial or Viral Meningitis Clinical Infectious Diseases 1997; 24:1240-1242.

13. Corsino Rey, Irene García-Hernández, Andrés Concha, Pablo Martínez-Camblor, Marta Botrán, Alberto Medina, Belén Prieto and Jesús López-Herce Pro-adrenomedullin, pro-endothelin-1, procalcitonin, Creactive protein and mortality risk in critically ill children: a prospective study Critical Care 2013, 17: R240 : p1-9.

14. Fernández Lopez A, Luaces Cubells C, García García JJ, Fernández Pou J. Procalcitonin in pediatric emergency departments for the early diagnosis of invasive bacterial infections in febrile infants: results of a multicenter study and utility of a rapid qualitative test 
for this marker. Pediatr Infect Dis J. 2003 Oct; 22(10): 895-903.

15. Andreola B, Bressan S, Callegaro S, Liverani A, Plebani M, Da Dalt L. Procalcitonin and C-reactive protein as diagnostic markers of severe bacterial infections in febrile infants and children in the emergency department. Pediatr Infect Dis J. 2007 Aug; 26(8): 672-677.

16. Carrol ED, Newland $\mathrm{P}$, Riordan FA, et al. Procalcitonin as a diagnostic marker of meningococcal disease in children presenting with fever and a rash. Arch Dis Child 2002; 86: 282-285.

17. Vincenzo Maniaci, Andrew Dauber, Scott Weiss, Eric Nylen, Kenneth L. Becker, Richard Bachur. Procalcitonin in Young Febrile Infants for the Detection of Serious Bacterial Infections. Pediatrics 2008; 122: 701-710.

18. Mark Hatherill, Shane M Tibby, Kim Sykes, Charles Turner, Ian A Murdoch Diagnostic markers of infection: comparison of procalcitonin with $\mathrm{C}$ reactive protein and leucocyte count. Arch Dis Child 1999; 81: 417-421.

19. Liliana Simon, France Gauvin, Devendra K. Amre, Patrick Saint-Louis, and Jacques LacroixSerum Procalcitonin and C-Reactive Protein Levels as Markers of Bacterial Infection: A Systematic Review and Metaanalysis Clinical Infectious Diseases 2004; 39: 206-17.

20. Deis JN, Creech CB, Estrada CM, Abramo TJ. Procalcitonin as a marker of severe bacterial infection in children in the emergency department. Pediatr Emerg Care. 2010; 26: 51-60.

\section{How to cite this article?}

Simhachalam M, Vasundhara A, Swetha L, Sudarsini P. Comparative study of procalcitonin versus c-reactive protein in the diagnosis of sepsis in children below 16 years-a single centre observational study. J PediatrRes.2017;4(01):6875.doi:10.17511/ijpr.2017.i01.14 